University of Nebraska - Lincoln

DigitalCommons@University of Nebraska - Lincoln

USDA National Wildlife Research Center - Staff Publications
U.S. Department of Agriculture: Animal and Plant Health Inspection Service

2010

\title{
Laboratory Efficacy of Chemical Repellents for Reducing Blackbird Damage in Rice and Sunflower Crops
}

\author{
Scott J. Werner \\ USDA/APHIS/ WS/ National Wildlife Research Center, scott.j.werner@aphis.usda.gov
}

George M. Linz

USDA/APHIS/WS National Wildlife Research Center, george_m_linz@yahoo.com

Shelagh K. Tupper

USDA-APHIS, Wildlife Services' National Wildlife Research Center, shelagh.t.deliberto@usda.gov

James C. Carlson

USDA/APHIS/WS National Wildlife Research Center, james.c.carlson@aphis.usda.gov

Follow this and additional works at: https://digitalcommons.unl.edu/icwdm_usdanwrc

Werner, Scott J.; Linz, George M.; Tupper, Shelagh K.; and Carlson, James C., "Laboratory Efficacy of Chemical Repellents for Reducing Blackbird Damage in Rice and Sunflower Crops" (2010). USDA National Wildlife Research Center - Staff Publications. 1348.

https://digitalcommons.unl.edu/icwdm_usdanwrc/1348

This Article is brought to you for free and open access by the U.S. Department of Agriculture: Animal and Plant Health Inspection Service at DigitalCommons@University of Nebraska - Lincoln. It has been accepted for inclusion in USDA National Wildlife Research Center - Staff Publications by an authorized administrator of DigitalCommons@University of Nebraska - Lincoln. 


\title{
Laboratory Efficacy of Chemical Repellents for Reducing Blackbird Damage in Rice and Sunflower Crops
}

\begin{abstract}
SCOTT J. WERNER, ${ }^{1}$ United States Department of Agriculture, Animal and Plant Health Inspection Service, Wildlife Services, National Wildlife Research Center, 4101 LaPorte Avenue, Fort Collins, CO 80521-2154, USA

GEORGE M. LINZ, United States Department of Agriculture, Animal and Plant Health Inspection Service, Wildlife Services, National Wildlife Research Center, North Dakota Field Station, 2110 Miriam Circle, Bismarck, ND 58501-2502, USA

SHELAGH K. TUPPER, United States Department of Agriculture, Animal and Plant Health Inspection Service, Wildlife Services, National Wildlife Research Center, 4101 LaPorte Avenue, Fort Collins, CO 80521-2154, USA

JAMES C. CARLSON, United States Department of Agriculture, Animal and Plant Health Inspection Service, Wildlife Services, National Wildlife Research Center, 4101 LaPorte Avenue, Fort Collins, CO 80521-2154, USA

ABSTRACT Nonlethal alternatives are needed to manage blackbird (Icterids) damage to rice and sunflower production in the United States. We evaluated 4 registered fungicides on rice seeds (i.e., Allegiance ${ }^{\circledR}$ FL, Thiram 42-S, Trilex ${ }^{\circledR}$, and Vitavax ${ }^{\circledR} 200$ preplant seed treatments) and 2 foliar pesticides on sunflower seeds (Cobalt ${ }^{\mathrm{TM}}$ insecticide and Flock Buster bird repellent) as candidate blackbird repellents. Red-winged blackbirds (Agelaius phoeniceus) preferred untreated rice relative to rice treated with Thiram $(P<0.001)$ and Vitavax $(P<0.001)$, and untreated sunflower relative to sunflower treated with Cobalt $(P<0.001)$. Blackbirds preferred untreated sunflower relative to sunflower treated with Flock Buster repellent on day 1 of a 4 -day preference test $(P<0.001)$. We observed no difference in consumption of treated versus untreated rice during the Allegiance preference test $(P=0.928)$, and blackbirds preferred rice treated with Trilex relative to untreated rice $(P=$ 0.003). Although repellency was positively related to tested concentrations of Thiram $(P=0.010)$, Trilex $(P=0.026)$, and Vitavax $(P<$ 0.001), maximum repellency was $<50 \%$ during our concentration-response tests of these seed treatments. Repellency was also positively related to tested concentrations of Cobalt $(P<0.001)$, and we observed $>80 \%$ repellency of sunflower treated with Cobalt at $\geq 50 \%$ of the label rate. We observed no concentration-response relationship for the Allegiance seed treatment $(P=0.341)$ and Flock Buster repellent $(P=0.952)$. We recommend implementation of supplemental field studies to compare laboratory efficacy, repellency, and chemical residues of effective avian repellents throughout periods of needed crop protection.
\end{abstract}

KEY WORDS Agelaius phoeniceus, carboxin, chemical repellent, chlorpyrifos, gamma-cyhalothrin, metalaxyl, red-winged blackbird, thiram, trifloxystrobin, wildlife damage management.

Depredating blackbirds (Icterids) can negatively impact growth of newly planted rice in the mid-South of the United States and production of ripening rice and sunflower (Cummings et al. 2002; Avery et al. 2005; Werner et al. 2005, 2007, 2008a). Cummings et al. (2005) estimated that blackbirds caused approximately US\$13.4 million of damage to United States rice production in 2001. Blackbird damage to ripening sunflower was estimated to be US\$5.4 million annually (Peer et al. 2003), or approximately $2 \%$ of the total value of the annual crop in the United States (Kleingartner 2003). The term blackbirds typically includes red-winged blackbirds (Agelaius phoeniceus), common grackles (Quiscalus quiscula), brown-headed cowbirds (Molothrus ater), and yellow-headed blackbirds (Xanthocephalus xanthocephalus). Although blackbird populations are generally declining throughout the United States, blackbird abundance has increased in recent years within the rice and sunflower growing regions (Sauer et al. 2008). The red-winged blackbird remains the most abundant bird in North America (Dolbeer 1990).

In addition to scare devices (e.g., propane cannons) and lethal management, chemical repellents may provide nonlethal approaches to managing blackbird depredation of agricultural crops. The purpose of our laboratory efficacy tests was to facilitate development of effective avian repellents for crop protection. Effectiveness of avian

${ }^{1}$ E-mail: Scott.J.Werner@aphis.usda.gov repellents for crop protection is dependent upon their 1) efficacy under field conditions, 2) cost relative to expected damages of unmanaged crops, 3) food and feed safety, and 4) environmental impacts. Registration of agricultural pesticides is dependent upon demonstrated efficacy and safety standards to protect human health and the environment. Our objective was to evaluate 4 registered fungicides (i.e., preplant seed treatments) on rice seeds, and a registered insecticide and a newly available bird repellent on sunflower seeds as candidate blackbird repellents.

\section{METHODS}

We conducted preference and concentration-response tests in 2007-2008 at the United States Department of Agriculture, National Wildlife Research Center's (NWRC) outdoor animal research facility in Fort Collins, Colorado, USA. We maintained our study population of red-winged blackbirds in $4.9 \times 2.4 \times 2.4-\mathrm{m}$ cages $(25-40$ birds/cage) within an open-sided building for $\geq 2$ weeks prior to testing. We provided free access to water, grit, and maintenance food to all birds during quarantine and holding. The maintenance diet for rice tests included 2 parts millet, 1 part milo, 1 part safflower, and 1 part sunflower. The maintenance diet for sunflower tests included 2 parts millet, 1 part cracked corn, 1 part milo, and 1 part safflower.

We conducted feeding tests within individual cages $(0.9 \times$ $1.8 \times 0.9 \mathrm{~m})$ in an open-sided building. We conducted 
preference and concentration-response tests concurrently for each candidate repellent. We tested Trilex (Bayer Crop Science, Research Triangle Park, NC) in February 2007, Vitavax (Bayer Crop Science) in January 2008, Thiram (Bayer Crop Science) in February 2008, Allegiance (Bayer Crop Science) in March 2008, and Cobalt (Dow AgroSciences, Indianapolis, IN) and Flock Buster (Skeet-RGone, Grand Forks, ND) in April 2008.

\section{Candidate Repellents and Evaluated Formulations}

We evaluated 4 registered, preplant seed treatments as candidate blackbird repellents for rice. We evaluated Allegiance $^{\circledR}$ FL (active ingredient [a.i.] 28.35\% metalaxyl: Chemical Abstracts Service [CAS] no. 57837-19-1), Thiram 42-S (a.i. 42\% thiram: CAS no. 137-26-8), Trilex ${ }^{\circledR}$ (a.i. $22 \%$ trifloxystrobin: CAS no. 141517-21-7), and Vitavax ${ }^{\circledR} 200$ fungicides (a.i. 17\% thiram, 17\% carboxin: CAS no. 5234-68$4)$ in a series of captive feeding tests with treated rice seed.

Linz et al. (2006) and Werner et al. (2008b) previously evaluated Lorsban ${ }^{\circledR}-4 \mathrm{E}$ (a.i. 44.9\% chlorpyrifos; Dow AgroSciences), Warrior T ${ }^{\circledR}$ (a.i. 11.4\% lambda-cyhalothrin; Syngenta Crop Protection, Inc., Greensboro, NC), and Karate $^{\circledR}$ with Zeon Technology ${ }^{\mathrm{TM}}$ (a.i. 22.8\% lambdacyhalothrin; Syngenta) as candidate blackbird repellents for sunflower and rice. In contrast to pyrethroid insecticides, Linz et al. (2006) observed decreased feeding rates (i.e., 81\% repellency) among red-winged blackbirds offered sunflower seeds treated with an organophosphorus insecticide (i.e., chlorpyrifos). We, therefore, tested a newly registered formulation of chlorpyrifos (i.e., Cobalt ${ }^{\mathrm{TM}}$ insecticide) and a newly available avian repellent (Flock Buster) as candidate blackbird repellents for sunflower.

We evaluated Cobalt insecticide and Flock Buster repellent in captive feeding tests with treated sunflower seed. Active ingredients of Cobalt were $30.00 \%$ chlorpyrifos (CAS no. 2921-88-2) and 0.54\% gamma-cyhalothrin (CAS no. 76703-62-3). Active ingredients of Flock Buster repellent were $3 \%$ lemon grass oil, $2 \%$ garlic oil, $2 \%$ clove oil, $3 \%$ peppermint oil, $2 \%$ rosemary oil, $2 \%$ thyme oil, and $3 \%$ white pepper.

We formulated treatments based upon the manufacturer's label (i.e., 100\% label rate) for each candidate repellent. Label rates of Bayer seed treatments were up to $1.0 \mathrm{~mL}$ Allegiance FL/ $\mathrm{kg}$ rice seed, $1.9 \mathrm{~mL}$ Thiram $42-\mathrm{S} / \mathrm{kg}$, up to $0.42 \mathrm{~mL}$ Trilex $/ \mathrm{kg}$, and $2.6 \mathrm{~mL}$ Vitavax $200 / \mathrm{kg}$. Label rates associated with our sunflower tests were up to $2.8 \mathrm{~L}$ Cobalt insecticide/ ha (per application) and $625 \mathrm{~mL}$ Flock Buster/ha for the first application of a 1:75 aqueous dilution. We applied aqueous treatment solutions $(60 \mathrm{~mL} / \mathrm{kg}$ rice and $75 \mathrm{~mL} / \mathrm{kg}$ sunflower) to certified seed rice (Louisiana State University Rice Research Station, Crowley, LA) and whole oilseed sunflower (Ranch-Way Feed Mills, Fort Collins, CO) using a rotating mixer (5 min) and disposable spray equipment. We air-dried all seed treatments within a chemical fume hood for 24 hours prior to testing and completed all tests within 7 days of treatment formulations. We formulated Cobalt and Flock Buster treatments based upon an average yield estimate of $626 \mathrm{~kg}$ sunflower/ha (Linz et al. 2006).

\section{Preference Testing}

We conducted a preference test (i.e., standardized laboratory efficacy test) for each seed treatment to determine whether blackbirds could discriminate between treated and untreated rice seeds. We used a cannon net to capture 44 experimentally naïve red-winged blackbirds (ad M) near Fort Collins, Colorado and transported them to NWRC. We randomly assigned 11 blackbirds to each of 4 tests (Allegiance, Thiram, Trilex, Vitavax). We transferred all birds to individual cages following group quarantine and holding, and offered them untreated seed rice (ad libitum) in each of 2 plastic food bowls (30 $\mathrm{cm}$ wide $\times 9 \mathrm{~cm}$ high) for 5 days of acclimation. We provided all birds water ad libitum throughout preference testing (i.e., acclimation, test).

We also conducted a preference test for Cobalt insecticide and Flock Buster repellent to determine whether blackbirds could discriminate between treated and untreated sunflower seeds. We used a cannon net to capture 22 experimentally naïve red-winged blackbirds (ad M) in 2008 near Fort Collins, Colorado and transported them to NWRC. We randomly assigned 11 blackbirds to each of the 2 sunflower tests. We repeated all acclimation procedures used during rice preference testing during our sunflower tests.

To conduct preference tests, we offered one plastic bowl $(30 \mathrm{~cm}$ wide $\times 9 \mathrm{~cm}$ high) of untreated seeds $(30 \mathrm{~g})$ and one bowl of seeds $(30 \mathrm{~g})$ treated with one of the candidate repellents to all birds during each day of the 4-day test (Monday-Thursday). We randomized the north-south positioning of treatments within individual cages on the first day and alternated positioning on subsequent days of the test to overcome potential side preferences (independent of treatments; Werner et al. 2007, 2008a, b, 2009). We measured test consumption independently for food bowls located on the north and south sides of each cage. We collected uneaten seeds (i.e., those remaining in food bowls) and seed spillage (those remaining in trays beneath each bowl) at 0800-0930 hours daily (Tuesday-Friday), and determined the mass $( \pm 0.1 \mathrm{~g})$ of each. We accounted for daily changes in seed mass independent of consumption (e.g., desiccation) by weighing seed offered within a vacant cage throughout the test.

The dependent measure for preference testing was average (i.e., daily) test consumption of treated and untreated seeds. We analyzed consumption data for each preference test using a repeated measures analysis of variance (ANOVA). The random effect of our models was bird subjects, the betweensubjects effect was treatment (treated vs. untreated seed), and the within-subject effect was test day. We evaluated the treatment effect and treatment-by-day interaction using the mixed procedure (SAS Institute, Cary, NC). We used Tukey's tests to separate means of ANOVA interactions ( $\alpha$ $=0.05)$. We used descriptive statistics $(\bar{x} \pm \mathrm{SE})$ to summarize test consumption of treated and untreated seeds.

\section{Concentration-Response Testing}

In supplement to our preference tests, we conducted a concentration-response test for each candidate repellent to evaluate efficacy. We used a cannon net to capture 257 experimentally naïve red-winged blackbirds (ad M) near 
Fort Collins, Colorado, and transported them to NWRC. We randomly assigned 42-44 blackbirds to each of 4 tests for rice (Allegiance, Thiram, Trilex, Vitavax) and 2 tests for sunflower (Cobalt, Flock Buster). We transferred all birds to individual cages following group quarantine and holding, and offered them untreated seed rice or whole oilseed sunflower (ad libitum) in one plastic food bowl $(30 \mathrm{~cm}$ wide $\times 9 \mathrm{~cm}$ high) for 5 days of acclimation. We provided all birds water ad libitum throughout concentration-response testing (i.e., acclimation, pretreatment, test).

We offered $30 \mathrm{~g}$ of untreated seed in one plastic bowl $(30 \mathrm{~cm}$ wide $\times 9 \mathrm{~cm}$ high) to all birds during each day of the 3-day pretreatment (Monday-Wednesday). We collected uneaten seeds and seed spillage at 0800-0930 hours daily (TuesdayThursday), and determined the mass $( \pm 0.1 \mathrm{~g})$ of each. We accounted for daily changes in seed mass independent of consumption (e.g., desiccation) by weighing seeds offered within a vacant cage throughout the pretreatment and test.

For each candidate repellent, we ranked blackbirds based upon average pretreatment consumption and assigned them to 1 of 5 treatment groups $(n=8-9$ birds/group; Werner et al. 2007, 2008a, $b, 2009$ ) such that each group was similarly populated with birds that exhibited high-low daily consumption. We randomly assigned treatments among groups. We used treatment groups to evaluate repellency associated with $25 \%, 50 \%, 75 \%, 100 \%$, or $200 \%$ of the label rate for each candidate repellent. We repeated all formulation procedures used for preference tests for our concentrationresponse formulations. We offered $30 \mathrm{~g}$ of treated seed in one bowl to all birds on Thursday, and determined the mass $( \pm 0.1 \mathrm{~g})$ of uneaten seeds and seed spillage at 08000930 hours on Friday of concentration-response tests.

We hypothesized that repellency would be directly related to repellent concentration (Werner et al. 2007, 2008a, b, 2009). We predicted that test consumption associated with efficacious treatments would be $<25 \%$ (i.e., $\geq 75 \%$ repellency; Schneider 1982) of pretreatment consumption. The dependent measure for concentration-response testing was percent repellency (i.e., test consumption relative to average pretreatment consumption) as a function of repellent concentration. We used regression procedures (SAS Institute) to analyze repellency exhibited during concentration-response testing. We used descriptive statistics $(\bar{x} \pm \mathrm{SE})$ to summarize repellency of treated seeds. The NWRC Institutional Animal Care and Use Committee approved the capture, care, and use of birds associated with our rice (NWRC Study Protocol QA1443) and sunflower tests (QA1542).

\section{RESULTS}

\section{Preference Testing}

We observed no difference in consumption of rice treated with Allegiance seed treatment versus that of untreated rice $\left(F_{1,10}=0.01, P=0.928\right)$. On average, blackbirds consumed $5.4( \pm 0.5) \mathrm{g} / \mathrm{bird} /$ day of untreated rice and $5.5( \pm 0.5) \mathrm{g} /$ bird/day of rice treated with Allegiance (Fig. 1). We also observed no treatment-day interaction during the Allegiance preference test $\left(F_{6,60}=0.30, P=0.935\right)$.

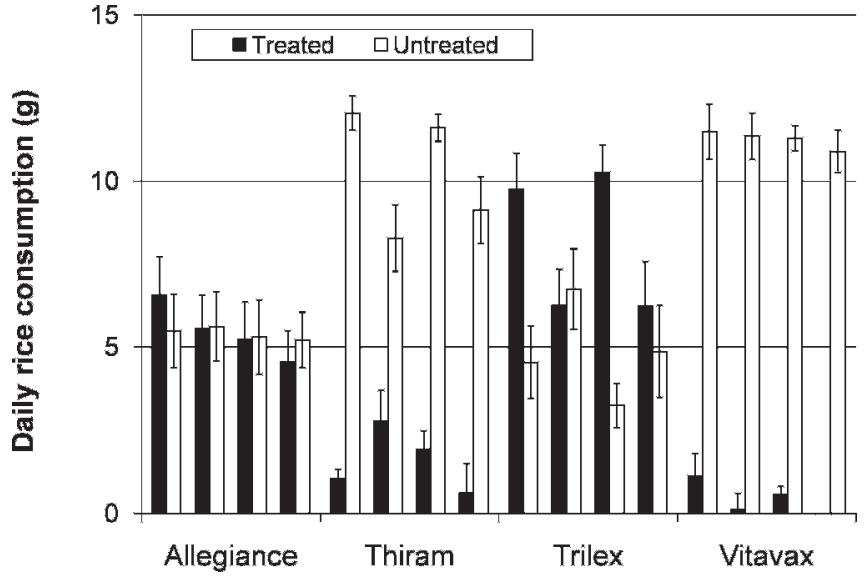

Figure 1. Rice consumption ( $\bar{x} \pm 1 \mathrm{SE})$ among red-winged blackbirds offered untreated rice and rice treated with the label rate of Allegiance ${ }^{\circledR} \mathrm{FL}$, Thiram 42-S, Trilex ${ }^{\circledR}$, or Vitavax ${ }^{\circledR} 200$ seed treatments (Bayer Crop Science, Research Triangle Park, NC) for 4 days at the National Wildlife Research Center in Fort Collins, Colorado, USA, February 2007March 2008

Blackbirds ate less rice treated with Thiram $\left(F_{1,10}=\right.$ 242.57, $P<0.001)$ and Vitavax $\left(F_{1,10}=659.19, P<0.001\right)$ than untreated rice during the preference test (Fig. 1). Average consumption during the Thiram test was 10.3 $( \pm 0.5) \mathrm{g} / \mathrm{bird} /$ day of untreated rice and $1.6( \pm 0.4) \mathrm{g} / \mathrm{bird} /$ day of treated rice. Blackbirds consumed more untreated rice than rice treated with Thiram during each of the 4 days of the preference test $\left(F_{6,60}=3.48, P=0.005\right)$. Average consumption during the Vitavax test was $11.3( \pm 0.3) \mathrm{g} /$ $\mathrm{bird} / \mathrm{day}$ of untreated rice and $0.2( \pm 0.3) \mathrm{g} / \mathrm{bird} / \mathrm{day}$ of treated rice. We observed no treatment-day interaction $\left(F_{6,60}=0.99, P=0.438\right)$ during the Vitavax preference test. Blackbirds consumed more rice treated with Trilex (8.1 $\pm 0.6 \mathrm{~g})$ than untreated rice $\left(4.9 \pm 0.6 \mathrm{~g} ; F_{1,10}=15.42, P\right.$ $=0.003)$. We also observed a treatment-day interaction during the Trilex preference test $\left(F_{6,60}=2.46, P=0.034\right)$, particularly on day 3 (Tukey $P=0.002$; Fig. 1 ).

We observed less consumption of sunflower treated with Cobalt insecticide than that of untreated sunflower $\left(F_{1,10}=\right.$ 443.14, $P<0.001)$. On average, blackbirds ate $8.6( \pm 0.4)$ $\mathrm{g} / \mathrm{bird} /$ day of untreated sunflower and $0( \pm 0.2) \mathrm{g} / \mathrm{bird} /$ day of sunflower treated with Cobalt (Fig. 2). We observed no treatment-day interaction $\left(F_{6,60}=0.61, P=0.719\right)$ during the Cobalt preference test.

Blackbirds consumed more untreated sunflower relative to that treated with Flock Buster $\left(F_{1,10}=7.36, P=0.022\right)$. On average, blackbirds ate $3.5( \pm 0.4) \mathrm{g} / \mathrm{bird} /$ day of untreated sunflower and $2.5( \pm 0.3) \mathrm{g} / \mathrm{bird} / \mathrm{day}$ of sunflower treated with Flock Buster (Fig. 2). We also observed a treatment-day interaction during the Flock Buster preference test $\left(F_{6,60}=\right.$ 8.37, $P<0.001$ ), particularly on day 1 (Tukey $P<0.001$ ).

\section{Concentration-Response Testing}

We observed no concentration-response relationship for the Allegiance seed treatment (Fig. 3). Repellency (i.e., test relative to pretreatment consumption) of rice treated with $25-200 \%$ of the Allegiance label rate was unrelated to tested 


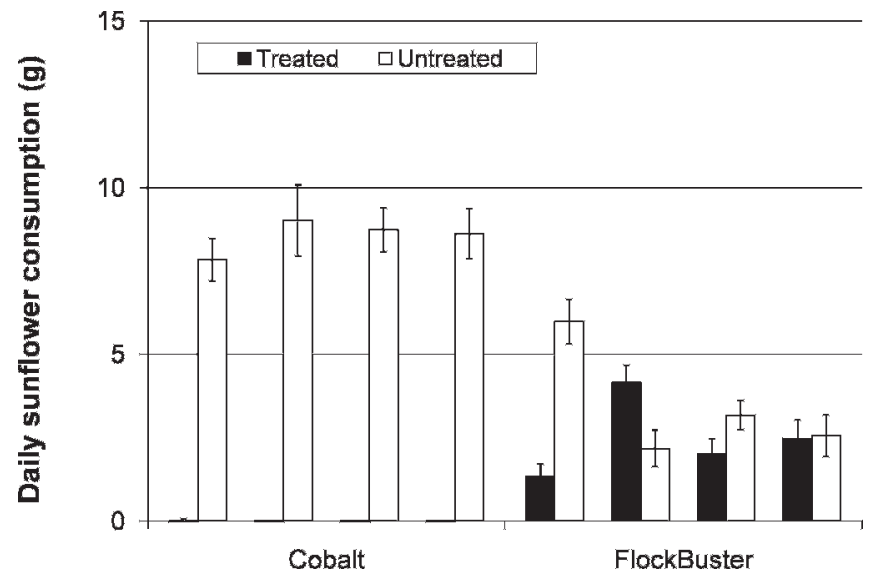

Figure 2. Sunflower consumption $(\bar{x} \pm 1 \mathrm{SE})$ among red-winged blackbirds offered untreated sunflower and sunflower treated with Cobalt ${ }^{\mathrm{TM}}$ insecticide (Dow AgroSciences, Indianapolis, IN) or Flock Buster repellent (Skeet-R-Gone, Grand Forks, ND) for 4 days at the National Wildlife Research Center in Fort Collins, Colorado, USA, April 2008.

concentrations $\left(r^{2}=0.022, P=0.341\right)$. Among tested concentrations, maximum repellency was $12 \%$ at the $25 \%$ Allegiance concentration (Fig. 3).

Repellency was related to tested concentrations of Thiram $\left(r^{2}=0.155, P=0.010\right)$, Trilex $\left(r^{2}=0.116, P=0.026\right)$, and Vitavax seed treatments $\left(r^{2}=0.571, P<0.001\right)$. Maximum repellency, however, was only 22\% at the 200\% Thiram label rate and $24 \%$ at the $100 \%$ Trilex label rate (Fig. 3). We observed $46 \%$ repellency at $200 \%$ of the Vitavax label rate during the concentration-response test (Fig. 3).

Repellency was also related to tested concentrations of Cobalt insecticide $\left(r^{2}=0.374, P<0.001\right)$. We observed $>80 \%$ repellency of sunflower treated with $\geq 50 \%$ of the Cobalt label rate (Fig. 4). Repellency was unrelated to tested concentrations of Flock Buster repellent $\left(r^{2}<0.001, P=\right.$ 0.952; Fig. 4).

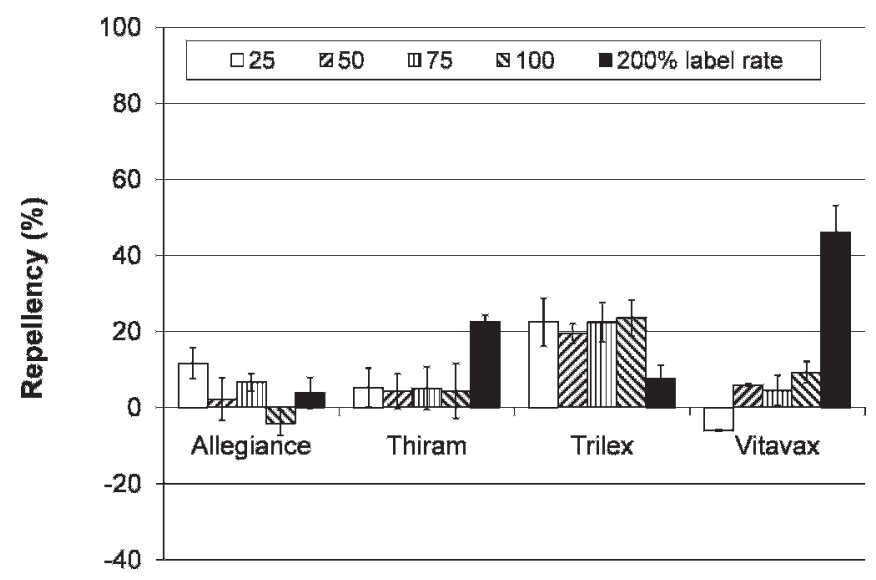

Figure 3. Avian repellency ( $\bar{x} \pm 1 \mathrm{SE})$ associated with 5 concentrations of Allegiance ${ }^{\circledR}$ FL, Thiram 42-S, Trilex ${ }^{\circledR}$, or Vitavax ${ }^{\circledR} 200$ seed treatments (Bayer Crop Science, Research Triangle Park, NC) at the National Wildlife Research Center in Fort Collins, Colorado, USA, February 2007-March 2008. Repellency represents test consumption relative to average pretreatment rice consumption ( $n=8-9$ red-winged blackbirds/group).

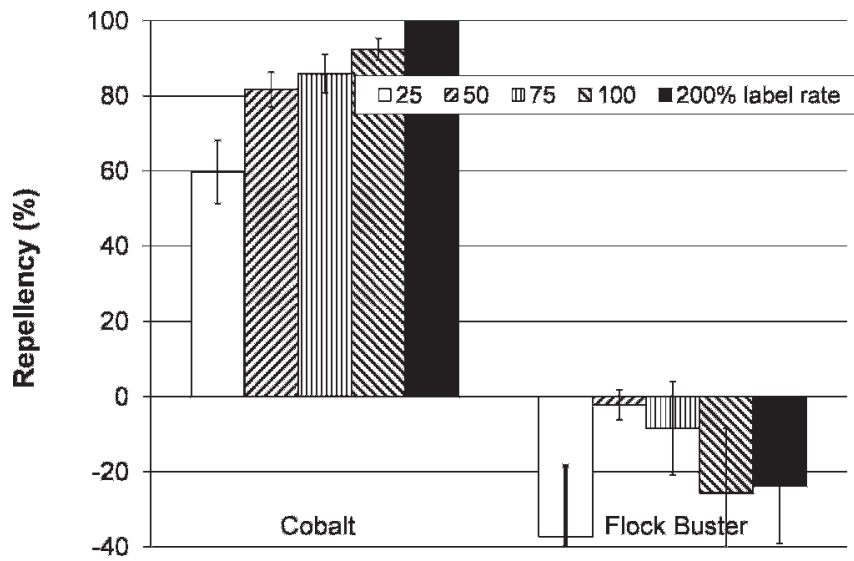

Figure 4. Avian repellency ( $\bar{x} \pm 1 \mathrm{SE}$ ) associated with 5 concentrations of Cobalt ${ }^{\mathrm{TM}}$ insecticide (Dow AgroSciences, Indianapolis, IN) or Flock Buster repellent (Skeet-R-Gone, Grand Forks, ND) at the National Wildlife Research Center in Fort Collins, Colorado, USA, April 2008. Repellency represents test consumption relative to average pretreatment rice consumption ( $n=8-9$ red-winged blackbirds/group).

\section{DISCUSSION}

We observed a treatment effect during our preference testing of rice seeds treated with Thiram and Vitavax, and sunflower seeds treated with Cobalt and Flock Buster; blackbirds thus discriminated between treated and untreated seeds. However, we observed $<50 \%$ repellency for all tested seed treatments and Flock Buster during our concentrationresponse tests; efficacious treatments would yield $\geq 75 \%$ repellency. We therefore recommend both preference testing and concentration-response testing to reliably evaluate laboratory efficacy of avian repellents (Werner et al. 2007, 2008a, b, 2009). Although we observed a concentration-response relationship for Thiram, maximum repellency was only $22 \%$. The current label rate for Thiram $42-\mathrm{S}$ is equivalent to $0.08 \%$ thiram ( $\mathrm{vol} / \mathrm{vol})$. In contrast, previous field efficacy studies of thiram seed treatments for wheat and sunflower included $0.5 \%$ of the active ingredient (wt/wt; Dhindsa and Saini 1994, Malhi 1997).

Among candidate repellents that we tested, Cobalt insecticide (a.i. chlorpyrifos and gamma-cyhalothrin) was the most effective for reducing seed consumption during concentration-response testing (i.e., $>80 \%$ repellency). Similarly, Linz et al. (2006) observed 81\% repellency of the full-label rate of Lorsban-4E insecticide (a.i. chlorpyrifos) and Werner et al. (2008b) observed 55\% repellency of Karate with Zeon Technology insecticide (a.i. lambdacyhalothrin) among red-winged blackbirds in captivity.

In addition to the cost-effectiveness of repellent applications, chemical repellents must not negatively affect food and feed safety, or environmental quality (e.g., target and nontarget toxicity). Red-winged blackbirds (60-g body mass $[\mathrm{BM}])$ offered sunflower treated with $25-200 \%$ of the Cobalt label rate consumed an average of 0-6.4 $\mathrm{g}$ of treated sunflower, or 0-48.4 mg chlorpyrifos/ $\mathrm{kg}$ BM during our nochoice, concentration-response test. The median lethal dose (acute $\mathrm{LD}_{50}$ ) of chlorpyrifos for birds is $51-500 \mathrm{mg} / \mathrm{kg}$ (Dow AgroSciences). The average dose of chlorpyrifos 
ingested among birds offered sunflower treated with $50 \%$ of the Cobalt label rate was $14.5 \mathrm{mg}$ chlorpyrifos $/ \mathrm{kg} \mathrm{BM}$; thus, $<30 \%$ of the median lethal dose yielded $82 \%$ repellency. Although the lethal threshold concentration (dietary $\mathrm{LC}_{50}$ ) of chlorpyrifos for birds is $0.005-0.05 \%$ chlorpyrifos (Dow AgroSciences), we observed no mortality among 55 redwinged blackbirds offered sunflower treated with 0.03$0.26 \%$ chlorpyrifos (wt/wt).

Our observations regarding repellency of Cobalt insecticide may be related to the $69.5 \%$ other ingredients of the formulated product. For example, the aromatic hydrocarbons and benzene derivatives associated with this formulation (Dow AgroSciences) may affect the chemical senses associated with avian repellency (Mason and Clark 2000). Additional laboratory efficacy studies (i.e., preference and concentrationresponse tests) are needed to discover the contribution that these additives may make for avian repellency.

\section{MANAGEMENT IMPLICATIONS}

Blackbird repellents are most needed to protect rice in the mid-South of the United States 3-4 weeks after planting and 3-4 weeks prior to harvest (Werner et al. 2008b, 2009). For ripening sunflower, $>75 \%$ of annual blackbird damage occurs within the first 18 days after anthesis (Cummings et al. 1989). The end of anthesis (i.e., flowering period) for sunflower is marked by the emergence of the last anther, which coincides with the beginning of yellow ray flower drop (Siddiqui 1975). On average (2003-2007), 65\% of the North Dakota sunflower crop had dried and dropped all ray flowers by 31 August, and 52\% of the North Dakota crop had been harvested by 26 October (i.e., 56 days subsequent to anthesis; National Agricultural Statistics Service-North Dakota Field Office 2008).

Thus, an effective avian repellent with a preharvest interval $\leq 55$ days could be cost-beneficial for agricultural producers; Cobalt insecticide meets this criterion (sunflower preharvest interval $=45$ days; Dow AgroSciences). Cobalt is, however, labeled by the United States Environmental Protection Agency only as an insecticide for use on alfalfa, Brussels sprouts, field corn and sweet corn, cotton, grain sorghum (milo), soybeans, sunflower, tree nuts, and wheat. It is a violation of federal law to use registered pesticides in a manner that is inconsistent with their labeling. Field efficacy research is needed to reconcile laboratory efficacy with field residues of seed treatments and foliar applications of effective avian repellents throughout periods of needed crop protection. Moreover, the spatial extent of inferences from our laboratory preference tests and the applicability of our concentration-response relationships should be evaluated under field conditions.

\section{ACKNOWLEDGMENTS}

This research was supported by the Louisiana Rice Research Board, the Louisiana State University Rice Research Station, the Rice Foundation, the U.S.A. Rice Federation, and the National Sunflower Association. Our rice tests were conducted with Bayer Crop Science seed treatments. Our sunflower tests were conducted with Cobalt insecticide
(Dow AgroSciences) and Flock Buster repellent (Skeet-RGone). Corporate collaborations do not imply endorsement by the United States Department of Agriculture. We appreciate the NWRC animal care staff that provided daily care throughout our feeding tests. We also thank J. Eisemann, S. Pettit, and B. Washburn for constructive feedback from their review of our manuscript.

\section{LITERATURE CITED}

Avery, M. L., S. J. Werner, J. L. Cummings, J. S. Humphrey, M. P. Milleson, J. C. Carlson, and T. M. Primus. 2005. Caffeine for reducing bird damage to newly seeded rice. Crop Protection 24:651-657.

Cummings, J. L., M. L. Avery, O. Mathre, E. A. Wilson, D. L. York, R. M. Engeman, P. A. Pochop, and J. E. Davis, Jr. 2002. Field evaluation of Flight Control ${ }^{\mathrm{TM}}$ to reduce blackbird damage to newly planted rice. Wildlife Society Bulletin 30:816-820.

Cummings, J. L., J. L. Guarino, and C. E. Knittle. 1989. Chronology of blackbird damage to sunflowers. Wildlife Society Bulletin 17:50-52.

Cummings, J. L., S. A. Shwiff, and S. K. Tupper. 2005. Economic impacts of blackbird damage to the rice industry. Wildlife Damage Management Conference 11:317-322.

Dhindsa, M. S., and H. K. Saini. 1994. Thiram protects sprouting wheat from house crows. International Pest Control 36:10-12.

Dolbeer, R. A. 1990. Ornithology and integrated pest management: redwinged blackbirds Agelaius phoeniceus and corn. Ibis 132:309-322.

Kleingartner, L. 2003. Sunflower losses to blackbirds: an economic burden. Pages 13-14 in G. M. Linz, editor. Management of North American blackbirds. U.S. Department of Agriculture, Washington, D.C., USA.

Linz, G. M., H. J. Homan, A. A. Slowik, and L. B. Penry. 2006. Evaluation of registered pesticides as repellents for reducing blackbird (Icteridae) damage to sunflower. Crop Protection 25:842-847.

Malhi, C. S. 1997. Prevention of bird damage at the sowing and sprouting stages of a sunflower crop. International Pest Control 39:127-128.

Mason, J. R., and L. Clark. 2000. The chemical senses in birds. Pages 3956 in G. C. Whittow, editors. Sturkie's avian physiology. Fifth edition. Academic Press, New York, New York, USA.

National Agricultural Statistics Service-North Dakota Field Office. 2008. North Dakota crop, livestock, and weather report. U.S. Department of Agriculture, Fargo, North Dakota, USA.

Peer, B. D., H. J. Homan, G. M. Linz, and W. J. Bleier. 2003. Impact of blackbird damage to sunflower: bioenergetic and economic models. Ecological Application 13:248-256.

Sauer, J. R., J. E. Hines, and J. Fallon. 2008. The North American Breeding Bird Survey, results and analysis 1966-2007. Version 5.15.2008. U.S Geological Survey, Patuxent Wildlife Research Center, Laurel, Maryland, USA.

Schneider, B. A. 1982. Pesticide assessment guidelines: subdivision G, product performance. U.S. Environmental Protection Agency, Office of Pesticide and Toxic Substances, Springfield, Virginia, USA.

Siddiqui, M. Q. 1975. Growth stages of sunflowers and intensity indices for white blister and rust. Plant Disease Reporter 59:7-11.

Werner, S. J., J. C. Carlson, S. K. Tupper, M. M. Santer, and G. M. Linz. 2009. Threshold concentrations of an anthraquinone-based repellent for Canada geese, red winged blackbirds, and ring-necked pheasants. Applied Animal Behaviour Science 121:190-196.

Werner, S. J., J. L. Cummings, P. A. Pipas, S. K. Tupper, and R. W. Byrd. 2008a. Registered pesticides and citrus terpenes as blackbird repellents for rice. Journal of Wildlife Management 72:1863-1868.

Werner, S. J., J. L. Cummings, S. K. Tupper, D. A. Goldade, and D. Beighley. 2008b. Blackbird repellency of selected registered pesticides. Journal of Wildlife Management 72:1007-1011.

Werner, S. J., J. L. Cummings, S. K. Tupper, J. C. Hurley, R. S. Stahl, and T. M. Primus. 2007. Caffeine formulation for avian repellency. Journal of Wildlife Management 71:1676-1681.

Werner, S. J., H. J. Homan, M. L. Avery, G. M. Linz, E. A. Tillman, A. A Slowik, R. W. Byrd, T. M. Primus, and M. J. Goodall. 2005. Evaluation of Bird Shield ${ }^{\mathrm{TM}}$ as a blackbird repellent in ripening rice and sunflower fields. Wildlife Society Bulletin 33:251-257.

Associate Editor: Messmer. 